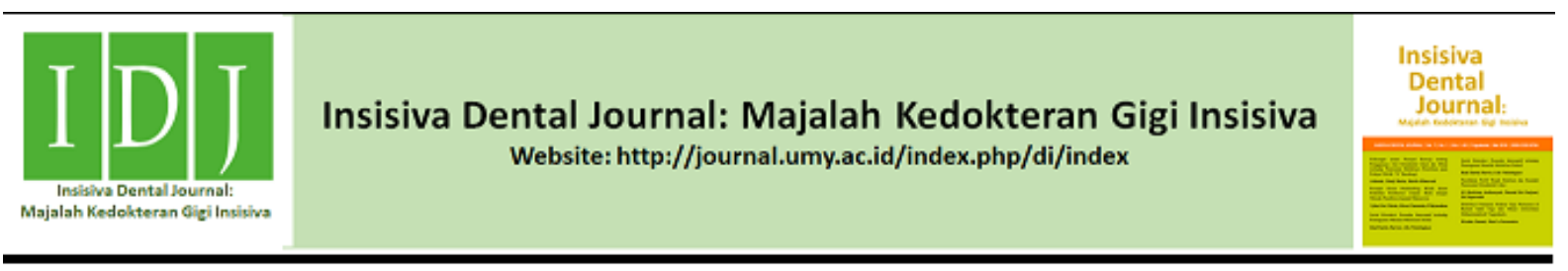

Research Article

\title{
Gambaran Pengetahuan terhadap Perawatan Ortodontik Menurut Islam pada Mahasiswa Kedokteran Gigi
}

\author{
Description of Knowledge on Orthodontic Treatment according to islam in Dentistry Students
}

\author{
Bayu Ananda Paryontri ${ }^{1}$, Alya Adisiyasha, ${ }^{2, *}$ \\ ${ }^{1}$ Departemen Ortodonsia, Program Studi Kedokteran Gigi, Fakultas Kedokteran dan Ilmu Kesehatan, Universitas Muhammadiyah \\ Yogyakarta, Jalan Brawijaya, Tamantirto, Kasihan, Bantul, Indonesia. \\ ${ }^{2}$ Program Studi Kedokteran Gigi, Fakultas Kedokteran dan Ilmu Kesehatan, Universitas Muhammadiyah Yogyakarta, Jalan Brawijaya, \\ Tamantirto, Kasihan, Bantul, Indonesia.
}

Received date: September $25^{\text {th }}, 2018$; reviewed: October $10^{\text {th }}, 2018$; revised date: November $10^{\text {th }}, 2018$; accepted date: Desember $11^{\text {st }}, 2018$ DOI : $10.18196 /$ di.8100

\begin{abstract}
Abstrak
Perawatan ortodontik bertujuan untuk menunjang kebersihan gigi dan mulut, memperbaiki fungsi mastikasi, fonetik, dan estetik. Hukum merapikan gigi dengan perawatan ortodontik dalam perspektif Islam dapat diketahui berdasarkan tujuannya. Pertama, bila merapikan gigi dengan tujuan estetika saja maka termasuk dalam kategori mengubah ciptaan Allah dan diharamkan. Sedangkan, jika ingin merapikan gigi dengan indikasi medis dan alasan kesehatan serta memperbaiki fungsi maka hukum diperbolehkan. Namun bila maloklusi gigi tidak mempengaruhi dalam fungsi dan hanya menganggu dalam penampilan, perawatan ortodontik tidak boleh dilakukan. Tujuan dari penelitian ini adalah untuk mengetahui gambaran pengetahuan terhadap perawatan ortodontik dalam Islam pada mahasiswa kedokteran gigi Universitas Muhammadiyah Yogyakarta (UMY). Metode penelitian ini adalah deskriptif observasional dengan rancangan cross sectional, dengan jumlah keseluruhan sampel 100 responden. Hasil penelitian menunjukkan bahwa tingkat pengetahuan perawatan ortodontik menurut Islam, sebagian besar mahasiswa kedokteran gigi UMY memiliki pengetahuan yang baik yaitu sebanyak 91 responden (91\%) dan pada kategori sedang sebanyak 9 responden (9\%). Kesimpulan penelitian ini adalah mahasiswa kedokteran gigi memiliki pengetahuan yang baik terhadap perawatan ortodontik menurut Islam.
\end{abstract}

Kata Kunci: Estetik; Hukum Ortodontik; Ortodontik Islam

\begin{abstract}
Orthodontic treatment aims to support dental and oral hygiene, improve the function of mastication, phonetics, and aesthetics. The law of correcting teeth with orthodontic treatment in the Islamic perspective can be known based on its purpose. First, if someone corrects the teeth with the purpose of aesthetic, it is included in the category of changing God's creation and is forbidden. Meanwhile, if someone wants to correct the teeth with medical indications, health reasons, and to improve the function, it is permitted. However, if the dental malocclusion does not affect the function and only interferes with the appearance of orthodontic care, it should not be done. The purpose of this study was to determine the description of knowledge on orthodontic treatment according to Islam of the dentistry students in the Universitas Muhammadiyah Yogyakarta (UMY). The method of this research was descriptive observational with a cross-sectional design with a total sample of 100 respondents. The results showed that the level of knowledge of orthodontic treatment according to Islam, most UMY dentistry students have good knowledge, as many as 91 respondents (91\%), and in the medium category as many as nine respondents (9\%). It could be concluded that UMY dentistry students have good knowledge of orthodontic treatment according to Islam.
\end{abstract}

Keywords: Aesthetics; Law of orthodontic; Islamic orthodontics

\footnotetext{
Corresponding author, e-mail: alyaadisiyasha@gmail.com
} 


\section{PENDAHULUAN}

Masyarakat Indonesia semakin menyadari bahwa fungsi gigi tidak hanya berperan dalam mastikasi namun berfungsi juga untuk menunjang penampilan. Hal ini seiring dengan berkembangannya ilmu dan perawatan ortodontik guna memenuhi kebutuhan serta tuntutan masyarakat. ${ }^{1}$ Motivasi seseorang dalam menjalani perawatan ortodontik cukup beragam, salah satunya yaitu karena perawatan ortodontik terutama alat ortodontik cekat sudah menjadi trend dalam hal estetika. ${ }^{2}$

Maloklusi pada bidang kedokteran gigi dapat diperbaiki melalui perawatan ortodontik sehingga kemampuan fonetik, mastikasi, dan estetik dapat meningkat dengan prinsip memperbaiki susunan gigi. ${ }^{3}$ Maloklusi secara harfiah diartikan sebagai kondisi oklusi yang tidak baik, atau menyimpang dari normal, yang mencegah gigi berkontak secara ideal. ${ }^{4}$ Penelitian yang dilakukan pada pasien ortodontik RSGM FKG UNHAS menunjukkan maloklusi berat dan butuh perawatan adalah sebesar 40\%. ${ }^{5}$ Maloklusi yang tidak dirawat dapat menimbulkan berbagai masalah seperti resiko karies dan penyakit periodontal, gangguan pada sendi temporomandibular, hingga tampilan wajah yang buruk. ${ }^{6}$

Perawatan ortodontik diperlukan untuk merawat maloklusi karena akan didapat gigi yang disejajarkan dengan baik sehingga lebih mudah untuk menjaga kebersihan serta kesehatan gigi dan mulut. ${ }^{7}$ Selain itu perawatan ortodontik dapat meningkatkan fungsi mastikasi, fonetik, dan estetik. Meskipun begitu dalam prosesnya perawatan ortodontik terjadi beberapa perubahan bentuk baik pada rahang maupun jaringan lunak pada wajah ${ }^{8}$ dan pada dasarnya Allah Subhanahu wa

Ta'ala melarang umat-umatnya untuk mengubah bentuk yang telah Allah Subhanahu wa Ta'ala anugerahkan,

Rasulullah Shallallahu Alaihi wa Sallam besabda:

"Allah melaknat wanita yang mentato dan wanita yang minta ditato, yang mencukur alis dan yang minta dicukur alisnya, serta yang merenggangkan giginya untuk kecantikan, yang merubah ciptaan Allah." (Hadits Riwayat Bukhari 4886 dan Muslim 2125).

Hukum merapikan gigi dengan perawatan ortodontik dalam perspektif Islam dapat diketahui berdasarkan tujuannya. Pertama, bila merapikan gigi dengan tujuan estetika saja maka termasuk dalam kategori mengubah ciptaan Allah dan diharamkan. Sedangkan jika ingin merapikan gigi dengan indikasi medis dan alasan kesehatan serta memperbaiki fungsi, maka hukum diperbolehkan. Maloklusi yang bersifat destruktif karena dapat menganggu fungsi mastikasi, fonasi, meningkatkan risiko karies serta penyakit periodontal dapat dilakukan perawatan ortodontik dan hukumnya boleh dalam islam. Namun bila maloklusi gigi tidak mempengaruhi dalam fungsi dan hanya menganggu dalam penampilan, perawatan ortodontik tidak boleh dilakukan karena masuk dalam kategori mengubah ciptaan Allah yang diharamkan. ${ }^{9}$

Haramnya merapikan gigi dengan tujuan yang hanya untuk estetika menjadi poin penting yang seharusnya diketahui para dokter gigi maupun calon dokter gigi sehingga penelitian untuk mengetahui gambaran pengetahuan terhadap perawatan ortodontik dalam Islam pada mahasiswa kedokteran gigi menarik untuk dilakukan.

\section{MATERIAL DAN METODE}

Penelitian ini menggunakan metode penelitian observasional deskriptif dengan desain penelitian cross-sectional dan jenis data kuantitatif menggunakan kuesioner. Penelitian ini dilakukan pada bulan Januari - April 2019 di Program Studi Pendidikan Kedokteran Gigi Fakultas Kedokteran dan Ilmu Kesehatan UMY.

Populasi dalam penelitian ini adalah mahasiswa kedokteran gigi UMY angkatan 2015, 2016, 2017, dan 2018. Subjek dalam penelitian ini adalah mahasiswa aktif kedokteran gigi UMY angkatan 2015 hingga 2018 periode tahun ajaran 
2018/2019, beragama Islam, dan bersedia menjadi partisipan penelitian bersifat sukarela.

Penentuan subjek penelitian menggunakan teknik stratified random sampling yaitu sampel diambil dengan membagi populasi menjadi beberapa strata dimana sifat setiap strata adalah homogen, sedangkan antarstrata terdapat sifat yang berbeda. Subjek dalam penelitian ini berjumlah 100 mahasiswa.

Variabel penelitian ini adalah variabel tunggal yaitu pengetahuan terhadap perawatan ortodontik menurut Islam pada mahasiswa kedokteran gigi UMY. Instrumen penelitian yang digunakan adalah kuesioner pengetahuan, Informed consent, alat tulis, dan komputer dengan software SPSS 15.0.

Penelitian ini menggunakan analisis data deskriptif yaitu bentuk dan analisis yang menyampaikan sebaran berupa frekuensi yang disajikan dalam bentuk tabel ataupun bentuk narasi. Deskripsi data terhadap variabel tunggal dalam penelitian ini berdasarkan nilai rata-rata (mean) pada tiap item pertanyaan dengan skor terendah 1 (sangat tidak setuju) dan skor tertinggi 5 (sangat setuju).

HASIL

Tabel 1. Gambaran karakteristik responden

\begin{tabular}{llcc}
\hline No. & $\begin{array}{c}\text { Karakteristik } \\
\text { Responden }\end{array}$ & Jumlah & $\begin{array}{c}\text { Persentase } \\
(\boldsymbol{\%})\end{array}$ \\
\hline $\mathbf{1}$ & Usia & & \\
& $\leq 20$ & 61 & 61 \\
& $>20$ & 39 & 39 \\
\hline $\mathbf{2}$ & Jenis Kelamin & & \\
& Laki-laki & 16 & 16 \\
& Perempuan & 84 & 84 \\
\hline $\mathbf{3}$ & Status & & \\
& Penggunaan & 38 & 38 \\
& Pernah & 62 & 62 \\
& Tidak Permah & & \\
\hline 4 & Angkatan & & \\
& 2015 & 28 & 28 \\
& 2016 & 24 & 24 \\
& 2017 & 25 & 25 \\
& 2018 & 23 & 23 \\
\hline & Total & 100 & 100 \\
\hline
\end{tabular}

Tabel 2. Gambaran pengetahuan perawatan ortodontik menurut islam pada mahasiswa kedokteran gigi UMY

\begin{tabular}{lcc}
\hline Pengetahuan & Jumlah & $\begin{array}{c}\text { Persentase } \\
(\boldsymbol{\%})\end{array}$ \\
\hline Sedang & 9 & 9 \\
Baik & 91 & 91 \\
\hline Total & 100 & 100 \\
\hline
\end{tabular}

Tabel 3. Gambaran pengetahuan perawatan ortodontik menurut islam pada mahasiswa kedokteran gigi UMY berdasarkan usia

\begin{tabular}{ccc}
\hline \multirow{2}{*}{ Usia } & \multicolumn{2}{c}{ Pengetahuan } \\
\cline { 2 - 3 } & Sedang & Baik \\
\hline$\leq 20$ & 5 & 56 \\
$>20$ & 4 & 35 \\
\hline Total & 9 & 91 \\
\hline
\end{tabular}

Tabel 4. Gambaran pengetahuan perawatan ortodontik menurut islam pada mahasiswa kedokteran gigi UMY berdasarkan jenis kelamin

\begin{tabular}{ccc}
\hline \multirow{2}{*}{$\begin{array}{c}\text { Jenis } \\
\text { Kelamin }\end{array}$} & \multicolumn{2}{c}{ Pengetahuan } \\
\cline { 2 - 3 } & Sedang & Baik \\
\hline Laki-laki & 3 & 13 \\
Perempuan & 6 & 78 \\
\hline \multicolumn{1}{c}{ Total } & 9 & 91 \\
\hline
\end{tabular}

Tabel 5. Gambaran pengetahuan perawatan ortodontik menurut islam pada mahasiswa kedokteran gigi UMY berdasarkan angkatan

\begin{tabular}{ccc}
\hline \multirow{2}{*}{ Angkatan } & \multicolumn{2}{c}{ Pengetahuan } \\
\cline { 2 - 3 } & Sedang & Baik \\
\hline 2015 & 2 & 26 \\
2016 & 3 & 21 \\
2017 & 1 & 24 \\
2018 & 3 & 20 \\
\hline Total & 9 & 91 \\
\hline
\end{tabular}

Tabel 6. Gambaran pengetahuan perawatan ortodontik menurut islam pada mahasiswa kedokteran gigi UMY berdasarkan riwayat penggunaan piranti ortodontik

\begin{tabular}{ccc}
\hline \multirow{2}{*}{$\begin{array}{c}\text { Status } \\
\text { Penggunaan }\end{array}$} & \multicolumn{2}{c}{ Pengetahuan } \\
\cline { 2 - 3 } & Sedang & Baik \\
\hline Pernah & 4 & 34 \\
Tidak Pernah & 5 & 57 \\
\hline \multicolumn{1}{c}{ Total } & 9 & 91 \\
\hline
\end{tabular}

Tabel 1 menunjukkan bahwa usia terbanyak responden adalah kelompok usia $\leq 20$ tahun yang berjumlah 61 responden $(61 \%)$. Berdasarkan jenis kelamin, sebagian besar responden adalah perempuan yang berjumlah 84 responden $(84 \%)$. Berdasarkan angkatan, sebagian 
besar responden adalah mahasiswa angkatan 2015 yang berjumlah 28 responden $(28 \%)$. Berdasarkan status atau riwayat penggunaan behel/perawatan ortodontik, sebagian besar responden sebelumnya tidak pernah menggunakan behel atau menjalani perawatan ortodontik yang berjumlah 62 responden (62\%).

Berdasarkan Tabel 2 didapatkan hasil penelitian yang menunjukkan bahwa sebagian besar responden memiliki pengetahuan pada kategori baik sebesar 91 responden $(91 \%)$.

Tabel 3 menunjukkan bahwa mahasiswa kedokteran gigi UMY yang mempunyai pengetahuan dengan kategori baik didominasi oleh kelompok usia $\leq 20$ tahun.

Tabel 4 menunjukkan bahwa jenis kelamin mahasiswa kedokteran gigi UMY yang mempunyai pengetahuan kategori baik terbanyak adalah mahasiswa perempuan sebanyak 78 orang.

Tabel 5 menunjukkan bahwa mahasiswa kedokteran gigi UMY yang mempunyai pengetahuan kategori baik terbanyak adalah angkatan 2015 yang berjumlah 26 orang.

Tabel 6 menunjukkan bahwa mahasiswa kedokteran gigi UMY yang mempunyai pengetahuan kategori baik terbanyak adalah kelompok yang tidak ada riwayat penggunaan piranti ortodontik yaitu sejumlah 57 orang.

\section{PEMBAHASAN}

Berdasarkan hasil penelitian didapatkan 91 mahasiswa (91\%) memiliki gambaran pengetahuan yang baik tentang perawatan ortodontik menurut islam dan 9 mahasiswa (9\%) memiliki gambaran pengetahuan sedang tentang perawatan ortodontik menurut islam. Pengetahuan yang dimiliki seseorang dapat menjadi dasar seseorang dalam berperilaku dengan berpikir manfaat yang akan terjadi dengan adanya tindakan tersebut. ${ }^{10}$ Sehingga, pengetahuan yang tinggi pada mahasiswa kedokteran gigi mengenai perawatan orthodontik dalam islam dapat menjadi dasar dalam berperilaku sebagai seorang calon dokter gigi.

Secara keseluruhan pengetahuan mahasiswa kedokteran gigi masuk ke dalam kategori baik dan faktor yang mempengaruhi pengetahuan seseorang yaitu pendidikan, media, dan keterpaparan informasi. ${ }^{11}$ Pendidikan merupakan salah satu faktor yang mempengaruhi pengetahuan seseorang, karena bimbingan untuk memahami suatu hal adalah pendidikan. ${ }^{12}$ Pengetahuan yang baik didapat dari beberapa faktor yang dapat mempengaruhi tingkat pengetahuan yaitu jenis kelamin, usia, dan pendidikan. ${ }^{13}$

Berdasarkan dari pernyataan yang diajukan kepada responden terdapat 3 jawaban yang berada pada interval pengetahuan sedang yaitu pernyataan nomor 2, 8, dan 9. Peryataan nomor 2 yaitu membahas tentang tujuan pemakaian kawat kaitannya untuk menjaga kesehatan serta kebersihan gigi dan mulut, hal ini sesuai karena gigi yang disejajarkan dengan baik memudahkan untuk menjaga kebersihan serta kesehatan gigi dan mulut. ${ }^{7}$ Meskipun saat perawatan ortodontik pembentukan plak dapat meningkat, hingga terbentuknya kalkulus, lesi white spot, dan gingivitis. ${ }^{14}$

Rata-rata responden mempunyai pengetahuan yang sedang yaitu pada kuesioner nomor 8 tentang diperbolehkannya pemakaian kawat gigi/ behel menurut hadist riwayat Al-Bukhari dan Muslim yang berbunyi "Allah melaknat wanita yang mentato dan wanita yang minta ditato, yang mencukur alis dan yang minta dicukur alisnya, serta yang merenggangkan giginya untuk kecantikan, yang merubah ciptaan Allah." Pernyataan kuesioner nomor 9 yang masih berkaitan dengan hadistt tersebut pada pernyataan nomor 8 dimana laki-laki diperbolehkan menggunakan kawat gigi/behel. Pemakaian kawat gigi/behel menurut Islam dapat diketahui hukumnya berdasarkan tujuan dari pemakaiannya, dimana hal ini sudah dibahas oleh Majelis Ulama Indonesia Kota Bandung memutuskan bahwa pemakaian behel gigi untuk tujuan pengobatan, 
menormalkan gigi yang tumbuhnya tidak normal, dan mencegah dari timbulnya penyakit maka hukumnya halal, sementara pemakaian behel gigi untuk tujuan kecantikan tanpa indikasi medis dengan merubah bentuknya yang asli maka hukumnya haram. ${ }^{9}$

Responden memiliki pengetahuan yang baik terhadap 12 penyataan kuesioner yaitu nomor $1,3,4,5,6,7,10,11,12,13$, 14, dan 15. Pernyataan kuesioner nomor 1 tentang perawatan ortodontik adalah pemakaian kawat gigi/behel dimana perawatan ortodontik cekat lebih dikenal dengan sebutan behel yaitu pemasangan alat berupa kawat gigi untuk perawatan gigi maloklusi. ${ }^{15}$ Peryataan nomor 3, 4, 5 dan 7 sesuai dengan tujuan pokok perawatan ortodontik antara lain untuk mencegah terjadinya keadaan abnormal dari bentuk muka yang disebabkan oleh kelainan rahang dan gigi yang berhubungan dengan faktor estetis. Sementara berdasarkan faktor fungsi yaitu meningkatkan fungsi pengunyahan yang betul, mencegah dan menghilangkan cara pernafasan yang abnormal dari segi perkembangan gigi, dan mengoreksi cara bicara yang salah. Selain itu tujuan pokok perawatan ortodontik lainnya adalah meningkatkan kebersihan gigi dan mulut sehingga meningkatkan daya tahan gigi terhadap karies dan pencegahan kerusakan gigi terhadap penyakit periodontal. ${ }^{16}$

Responden memiliki pengetahuan yang baik terhadap pernyataan kuesioner nomor 6 tentang menjaga kesehatan serta kebersihan gigi dan mulut dianjurkan bagi seluruh umat Islam, hal ini sesuai dengan salah satu hadist, "Apabila tidak akan memberatkan ummatku, maka aku akan perintahkan kepada mereka untuk bersiwak (menyikat gigi) setiap kali berwudhu". (Hadist Riwayat Bukhari nomor 887 dan Muslim 252).

Responden memiliki pengetahuan yang baik terhadap pernyataan kuesioner nomor 10 tentang diperbolehkannya perawatan ortodontik untuk tujuan pengobatan dan nomor 11 tentang diperbolehkannya perawatan ortodontik untuk memperbaiki susunan gigi yang tidak teratur, hal ini sesuai dengan Asy-Syaikh Shalih bin Fauzan bin Abdillah al-Fauzan hafizhahullah berkata dalam fatwanya, semisal gigi nampak jelek dan ada kebutuhan untuk meratakan gigi ataupun dilakukan dalam rangka pengobatan atau menghilangkan ketidaknormalan atau keperluan lainnya, maka hukumnya tidak mengapa/ mubah.

Responden memiliki pengetahuan yang baik terhadap pernyataan kuesioner nomor 13 tentang tidak diperbolehkannya perawatan ortodontik menurut Islam untuk tujuan kecantikan tanpa indikasi medis dengan mengubah susunan gigi yang asli. Hal ini dianggap hal yang sia-sia dan termasuk mengubah ciptaan Allah.

"Rasulullah melaknat orang-orang yang memasang tato, menajamkan giginya, mencabut alis matanya, dan mengubah ciptaan Allah.” (HR. An-Nasa'I 5253).

Responden memiliki pengetahuan yang baik terhadap pernyataan kuesioner nomor 14 dan 15 tentang diperbolehkannya perawatan ortodontik menurut Islam kaitannya untuk memperbaiki fungsi bicara dan pengunyahan. Hal ini merupakan tujuan medis perawatan ortodontik sebagai cara untuk memperbaiki fungsi pengunyahan maupun fungsi bicara dan hukumnya diperbolehkan secara syar'i. ${ }^{9}$

\section{KESIMPULAN}

Berdasarkan hasil penelitian yang dilakukan pada 100 mahasiswa kedokteran gigi Universitas Muhammadiyah Yogyakarta mengenai gambaran pengetahuan perawatan ortodontik menurut Islam, maka dapat diambil kesimpulan secara umum, bahwa sebagian besar mahasiswa kedokteran gigi Universitas Muhammadiyah Yogyakarta memiliki pengetahuan yang baik tentang perawatan ortodontik menurut Islam.

\section{DAFTAR PUSTAKA}

1. Ardhana, W. Identifikasi Perawatan Ortodontik Spesialistik dan Umum. 
Majalah Kedokteran Gigi: 2013; 20(1): 1-8.

2. Yohana, W. The Importance Oral Health for the Patient with Fixed Orthodontic Appliance. 2007.

3. Notoatmojo, S. Kesehatan Masyarakat Ilmu dan Seni. Bandung: Rineka Cipta, 2007.

4. Scheid, R. C., dan Weiss, G. Woelfel. Anatomi Gigi (8 ed.). Jakarta: EGC. ppl 265-266, 2013.

5. Rosani, F. Penilaian Maloklusi berdasarkan Handicapping

Malocclusion Assessment Index (HMA) pada Pasien Ortodontik Di RSGM FKG UNHAS. Unhas Repository. (online), 2012. (http://repository.unhas.ac.id/handle/1 23456789/1029, diakses 20 Juli 2018)

6. Mitchell, L. An Introduction to Orthodontics (3 ed.). New York: Oxford University Press. 2007.

7. Phulari, B. S. Orthodontics Principles and Practice. New Delhi: Jaypee Brothers Medical Publisher. 8. 2011.

8. Proffit, W. R., W, H., Fields, M, D., dan Sarver. Contemporary Orthodontics (4 ed.). St.Louis: Mosby. 2007.

9. Majelis Ulama Indonesia. Tindakan Kedokteran Gigi pada Saat Puasa. Bandung: Bidang Fatwa MUI Kota Bandung. 2018.

10. Walgito. Pengantar Psikologi Umum. Jakarta: Percetakan Andi. Meliono, I. (2007). MPKT Modul. FK UI. 2004.

11. Meliono, I. MPKT Modul. FK UI. 2007.

12. Mubarak. Promosi Kesehatan: Sebuah Pengantar Proses Mengajar dalam Pendidikan. Yogyakarta: Graha Ilmu. 2007.

13. Zuliyani. Gambaran Tingkat Pengetahuan Anak Remaja tentang
Bahaya Rokok di SMP 2 Sanden Bantul. Universitas Muhammadiyah Yogyakarta. 2016.

14. Yatkin, S. Z. Appropiate oral hygiene motivation method for patint with fixed appliance. Angle Ortho, 2007; 77(6):1085-1089.

15. Cozzani, G. Garden of Orthodontics. Illionis: Quitessence Publishing co. 2000.

16. Sulandjari, H. Buku Ajar Ortodonsia I KGO I. Yogyakarta: Universitas Gadjah Mada. 2008. 